\title{
PROJECTING VALUE ADDED IN AGRICULTURE IN LATVIA
}

\author{
Irina Pilvere ${ }^{1}$, Agnese Krievina ${ }^{2}$, Aleksejs Nipers ${ }^{1}$ \\ ${ }^{1}$ Latvia University of Life Sciences and Technologies, Latvia; \\ ${ }^{2}$ Institute of Agricultural Resources and Economics, Latvia \\ irina.pilvere@1lu.lv, agnese.krievina@arei.lv, aleksejs.nipers@1lu.lv
}

\begin{abstract}
To generate projections for agricultural production in Latvia until 2050, the Latvian Agricultural Sector Analysis Model (LASAM) was developed in 2016. At that stage the model generated projections for so called "activity data", which are used for projection of the GHG (greenhouse gases) emissions from agriculture. Nevertheless, the model lacked socio-economic information, including information of the effects on value added, productivity and employment in agriculture, which can be used for policy analysis and planning, especially within the context of the debates about the new European Union (EU) Common Agricultural Policy (CAP) and Latvian Rural Development Plan 2021-2027. Within this research the LASAM was extended by a module of value added calculations. The objective of the research is to produce a projection of value added for the whole agriculture and individual agricultural sectors for the period until 2050 in Latvia for the baseline scenario, if the CAP will stay frozen after 2020. The subject of the study is projecting value added. We conclude that if the CAP will not be changed after 2020 (baseline scenario), the value added of agriculture in Latvia is expected to increase by $33 \%$ in 2030 and by $80 \%$ in 2050, compared with 2017.
\end{abstract}

Keywords: agriculture, modelling, value added.

\section{Introduction}

Agriculture in the EU plays an important role and it is regulated by the special CAP, which exists from 1962 and is one of the oldest EU policies. The CAP evolved over the years. Currently the CAP main objectives are to ensure a decent standard of living for farmers and to provide a stable and safe food supply at affordable prices for consumers. The last CAP reform was introduced in 2013 and was focused on 3 priorities: viable food production; sustainable management of natural resources and balanced development of rural areas throughout the EU [1]. Now it is not clear how the CAP will look after 2020, the debates are going on. But Europeans attach growing importance to agriculture: along with the development of rural areas, they regard it as a "very important" issue for the future" [2]. Agriculture also is a key sector for the achievement of many goals in the 2030 Agenda for Sustainable Development [3]. In Latvia, agriculture, forestry and fishing as a percentage of gross domestic product accounted for only $3.2 \%$ in 2016 [4], yet it has significant socio-economic impact [5].

All the EU countries and many stakeholders are participating in debates about future of the CAP, taking into account their own perspective and interests. Many countries are using modelling tools to project what will happen in different scenarios.

The EU decision makers have traditionally used the results of a wide range of quantitative tools in framing their choices among alternative policy instruments [6]. The agricultural modelling world has generated several models aiming at the analysis of the response of the sector to certain changes in exogenous mainly policy variables [7]. Modelling is a way of solving problems that occur in the real world. Modelling includes the process of mapping the problem from the real world to its model in the world of models, - the process of abstraction, - model analysis and optimization, and mapping the solution back to the real system [8]. In terms of economic growth, the long-time horizon of this study implies visualizing a world that, in principle, would be significantly different from the present one. According to some projections to 2050, the world would be immensely richer and characterized by less pronounced relative income gaps between developed and countries currently... [9]. For this reason, agriculture will play an important role also in the future, and unbiased and economically justified projections are required for making policy decisions. Considering that value added is an important indicator of an increase in the market value of a product due to economic activity, it is important to project value added in agriculture in order to identify the potential development of this sector.

The overall objective of the research is to produce a projection of value added for the whole agriculture and individual agricultural sectors for the period until 2050 in Latvia for the baseline scenario, if the CAP will stay frozen after 2020. 


\section{Materials and methods}

To generate projections for the Latvian agricultural sector, the LASAM model was developed in 2016. The model covers the following key agricultural industries: cereals (wheat, barley, rye, oats, triticale), oil crops (rapeseed), legumes, potato, vegetables, dairy and beef cattle, sheep, goats, horses, pigs, poultry and laying hens [10-12]. The model initially was developed as an econometric, recursive, dynamic, multi-period scenario model. Those projections primary was focused on "activity data" (agricultural areas, number of animals) and used to calculate projections of Latvian GHG emissions.

Within this research project the LASAM model was extended by a socio-economic module [13]. One of the model indicators shown in this paper is value added. In the model it is obtained as the value of output less the value of intermediate consumption - in accordance with the commonly used concept and definition. Thus, the value added analysed represents an increase in the market value of a product, which was created in the result of economic activity in Latvia [14]. Output side of the value added for the key agricultural sectors is calculated and projected by the model primary based on the area, animal numbers, production and price statistics, mainly obtained from the Central Statistical Bureau of Latvia [15], while the calculation and projection of the intermediate consumption largely relies on the Farm Accountancy Data Network (FADN) data [16]. The model is written in R language, using RStudio software.

\section{Results and discussion}

\section{Simulation of value added}

Value added is computed and projected based on the value of output and the value of intermediate consumption.

The value of output for all the kinds of agricultural produce is computed by multiplying the output of produce by the price of it; then, the data are aggregated for the key agricultural sectors. A projection of the value of output is made based on a projection of output and a projection of prices.

Intermediate consumption. To compute the value of intermediate consumption, the research used the share of intermediate consumption (\%) in the total value of output for the key agricultural sectors. The share of intermediate consumption was obtained from the data on FADN farms broken down by their specialization type: field crops, vegetables, permanent crops, dairy, other grazing livestock as well as granivores (pigs and poultry).

Further, the model computed the value of intermediate consumption as a share of the calculated value of output for the key agricultural sectors.

A projection of changes in the share of intermediate consumption was made to compute future values of intermediate consumption.

For field crop sector, the share of intermediate consumption (as a dependent variable) was projected according to a linear regression equation (OLS), in which the independent variable was the price of wheat:

$$
\text { ar_intmc_sha_reg }<-\operatorname{lm}\left(a r \_i n t m c \_s h a \_a r s p e c \sim w h \_p r i c e\right)
$$

where ar_intmc_sha_arspec - share of intermediate consumption in specialized field crop farms; wh_price - price of wheat.

The intercept of the regression equation was computed at 0.9766214 , coefficient -0.0014088 , $p=0.015$ (Table 1$)$.

Future values for the share of intermediate consumption were obtained by using the earlier-made projection of the price of wheat.

For vegetable sector, the share of intermediate consumption was projected according to a linear regression equation (OLS), with an independent variable - price of wheat:

$$
v e g \_i n t m c \_s h a \_r e g<-1 \mathrm{~m}\left(v e g \_i n t m c \_s h a \_v e g s p e c \sim w h \_p r i c e\right)
$$

where veg_intmc_sha_vegspec - share of intermediate consumption in specialized vegetable farms;

wh_price - price of wheat. 
The intercept of the regression equation equalled 0.4357630, coefficient $0.0012453, p=0.002$ (Table 1). Future values for the share of intermediate consumption were obtained by using the earliermade projection of the price of wheat.

Table 1

\section{Regression equation parameters for field crop and vegetable sector in Latvia in 2015 [13; 15; 16]}

\begin{tabular}{|c|c|}
\hline \multicolumn{2}{|c|}{ Parameters of the regression equation } \\
\hline Field crops & Vegetables \\
\hline $\begin{array}{l}\text { Coefficients: } \\
\text { Estimate Std. Error t value } \\
\text { (Intercept) } 0.97662140 .075168212 .99 \\
\text { wh_price[16:26] }-0.00140880 .0004711-2.99 \\
\text { Pr( > Itl) } \\
\text { (Intercept) } 0.00000039 * * * \\
\text { wh_price[16:26] } 0.0152 * \\
\text { Signif. codes: } \\
0 \text { ‘***' } 0.001 \text { ‘**' } 0.01 \text { '*’ } 0.05 \text { '.' } 0.1 \text { ' ' } 1 \\
\text { Residual standard error: } 0.058 \text { on } 9 \text { degrees of freedom } \\
\text { Multiple R-squared: } 0.4984 \text {, Adjusted R-squared: } 0.4427 \\
\text { F-statistic: } 8.943 \text { on } 1 \text { and } 9 \text { DF, p-value: } 0.01519\end{array}$ & $\begin{array}{l}\text { Coefficients: } \\
\quad \text { Estimate Std. Error t value } \\
\text { (Intercept) } 0.43576300 .04576119 .523 \\
\text { wh_price[16:26] } 0.00124530 .00028684 .342 \\
\quad \text { Pr( > It|) } \\
\text { (Intercept) } 0.00000537 * * * \\
\text { wh_price[16:26] } 0.00187 * * \\
\text { Signif. codes: } \\
0 \text { ‘***' } 0.001 \text { ‘**' } 0.01 \text { '*’ } 0.05 \text { ', } 0.1 \text { ' ‘ } 1 \\
\text { Residual standard error: } 0.03531 \text { on } 9 \text { degrees of freedom } \\
\text { Multiple R-squared: } 0.6769 \text {, Adjusted R-squared: } 0.641 \\
\text { F-statistic: } 18.85 \text { on } 1 \text { and } 9 \text { DF, p-value: } 0.001872\end{array}$ \\
\hline
\end{tabular}

For permanent crop sector, the share of intermediate consumption was projected according to a linear regression equation (OLS), in which the independent variable was the yield of fruits and berries:

$$
\text { fr_intmc_sha_reg }<-1 \mathrm{~m}\left(\mathrm{fr} \_i n t m c \_s h a \_p e r s p e c \sim f r \_y i e l d\right)
$$

where fr_intmc_sha_perspec - share of intermediate consumption in specialized permanent crop farms;

fr_yield - yield of fruits and berries.

The intercept of the regression equation was computed at 0.89543 , coefficient $-0.11216, p=0.008$ (Table 2).

Table 2

\section{Regression equation parameters for permanent crop and dairy sector in Latvia in 2015 [13; 15; 16]}

\begin{tabular}{|c|c|}
\hline \multicolumn{2}{|c|}{ Parameters of the regression equation } \\
\hline Permanent crops & Dairy sector \\
\hline 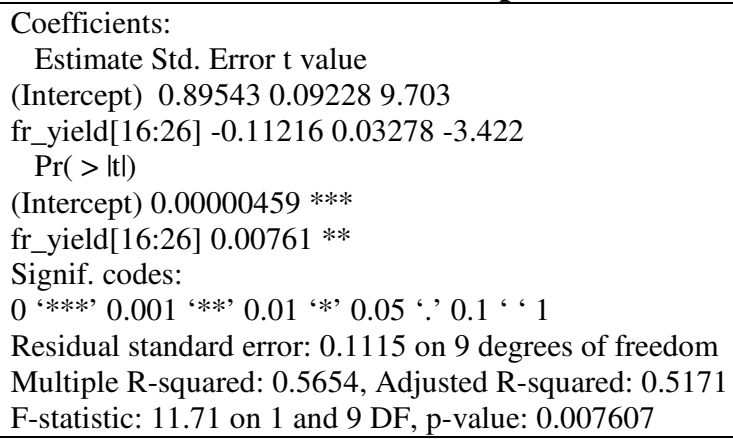 & 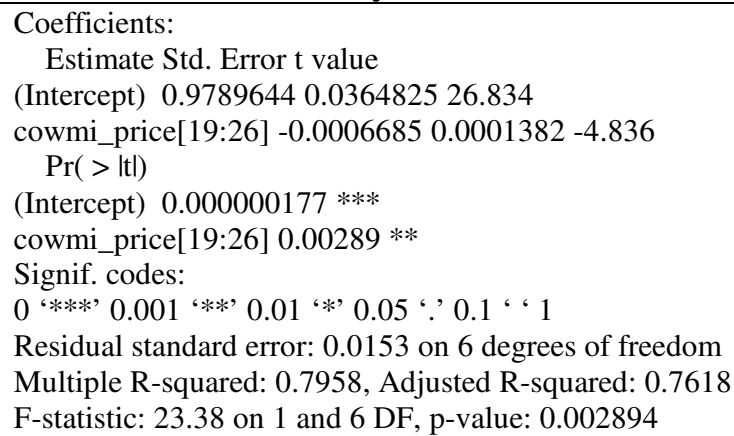 \\
\hline
\end{tabular}

Future values for the share of intermediate consumption were obtained by using the earlier-made projection of the yield of fruits and berries.

For dairy sector, the share of intermediate consumption was projected according to a linear regression equation (OLS), in which the independent variable was the price of milk:

$$
\text { cowmi_intmc_sha_reg }<-\operatorname{lm}(\text { cowmi_intmc_sha_dspec } \sim \text { cowmi_price })
$$

where cowmi_intmc_sha_dspec - share of intermediate consumption in specialized dairy farms; cowmi_price - price of milk.

The intercept of the regression equation was computed at 0.9789644 , coefficient -0.0006685 , $p=0.003$ (Table 2). 
Future values for the share of intermediate consumption were obtained by using the earlier-made projection of the price of milk.

For other grazing livestock sector, the share of intermediate consumption was projected according to a linear regression equation (OLS), in which the independent variable was the price of beef:

$$
g l \_i n t m c \_s h a \_r e g<-\operatorname{lm}\left(g l \_i n t m c \_s h a \_g l s p e c \sim c a \_p r i c e+d\right)
$$

where gl_intmc_sha_glspec - share of intermediate consumption in specialized other grazing livestock farms;

ca_price - price of beef;

$d$-dummy for the effect of the crisis of 2009.

The intercept of the regression equation was computed at 0.4940 , coefficients 0.0002573 and $0.1558, p=0.007$ (Table 3).

Table 3

Regression equation parameters for other grazing livestock and pig and poultry sector in Latvia in 2015 [13; 15; 16]

\begin{tabular}{|c|c|}
\hline \multicolumn{2}{|c|}{ Parameters of the regression equation } \\
\hline Other grazing livestock & Granivores \\
\hline Coefficients: & Coefficients: \\
\hline Estimate Std. Error t value & Estimate Std. Error t value \\
\hline (Intercept) 0.49400 .10964 .509 & (Intercept) 0.62646360 .053023711 .815 \\
\hline ca_price[16:26] 0.00025730 .000067083 .836 & wh_price[17:24] 0.00083690 .00031532 .655 \\
\hline d $\quad 0.15580 .057152 .726$ & $\operatorname{Pr}(>|t|)$ \\
\hline $\operatorname{Pr}(>|t|)$ & (Intercept) $0.0000222 * * *$ \\
\hline (Intercept) $0.00198 * *$ & wh_price[17:24] $0.0378 *$ \\
\hline ca_price[16:26] $0.00497 * *$ & Signif. codes: \\
\hline d $0.02601 *$ & 0 ‘***’ 0.001 ‘**’ 0.01 “*’ 0.05 ‘’ 0.1 “' 1 \\
\hline Signif. codes: & Residual standard error: 0.03129 on 6 degrees of \\
\hline 0 ‘***’ 0.001 ‘**’ 0.01 ‘*’ 0.05 ‘’ 0.1 ‘ ‘ 1 & freedom \\
\hline Residual standard error: 0.05405 on 8 degrees of freedom & Multiple R-squared: 0.5401 , Adjusted R-squared: 0.4635 \\
\hline Multiple R-squared: 0.7123, Adjusted R-squared: 0.6404 & F-statistic: 7.047 on 1 and 6 DF, p-value: 0.03779 \\
\hline F-statistic: 9.903 on 2 and 8 DF, p-value: 0.006851 & \\
\hline
\end{tabular}

Future values for the share of intermediate consumption were obtained by using the earlier-made projection of price on beef.

For granivores sector, the share of intermediate consumption was projected according to a regression equation, with an independent variable - price of wheat:

$$
p p \_i n t m c \_s h a \_r e g<-1 \mathrm{~m}\left(\mathrm{pp} \_i n t m c \_s h a \_p p s p e c \sim \text { wh_price }\right)
$$

where pp_intmc_sha_ppspec - share of intermediate consumption in specialized granivores farms;

wh_price - price of wheat.

The intercept of the regression equation was computed at 0.6264636 , coefficient 0.0008369 , $p=0.038$ (Table 3).

Future values for the share of intermediate consumption were obtained by using the earlier-made projection of price of wheat.

Value added is computed as a difference between the value of output and the value of intermediate consumption. Future value added was derived from the projections of the value of output and intermediate consumption.

\section{Projection of value added in main agricultural sectors}

Value added represents an increase in the market value of a product, which was created in the result of economic activity. The model computes value added by subtracting the value of intermediate consumption from the value of output (quantity times price).

Any change in the value added of agriculture is due to output and price fluctuations, and the value added has been volatile in the period after 2005. In view of the projections for the agriculture, a gradual increase in value added is expected (Figure 1). 


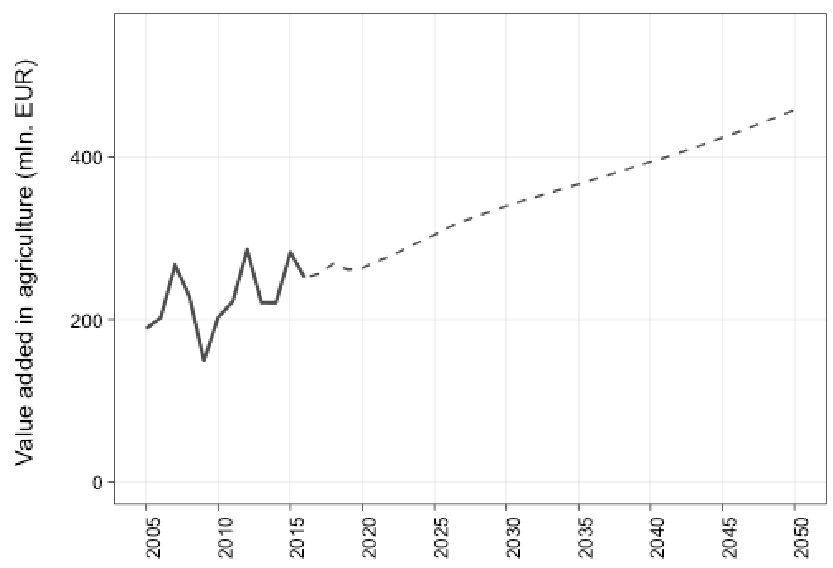

Fig. 1. Value added of agriculture in 2005-2016 and projection of it in Latvia for period $2017-2050$, mln. EUR [13; 15; 16]

According to the projection, the value added of agriculture is expected to reach EUR $460.1 \mathrm{mln}$. by 2050 , which is $80 \%$ more than in 2017 (EUR $256.3 \mathrm{mln}$.). The value added is projected to increase by 2030 too, reaching EUR $341.2 \mathrm{mln}$. ( + $33 \%)$.

The projection of the value added of field crops was positive, as output increases were projected for most of the crops (Figure 2).

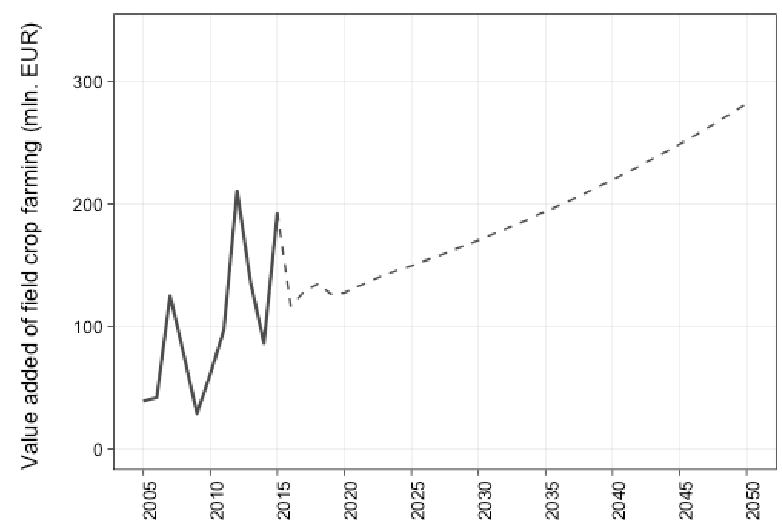

Fig. 2. Value added of field crop sector in 20052015 and projection of it in Latvia for period 2016-2050, mln. EUR [13; 15; 16]

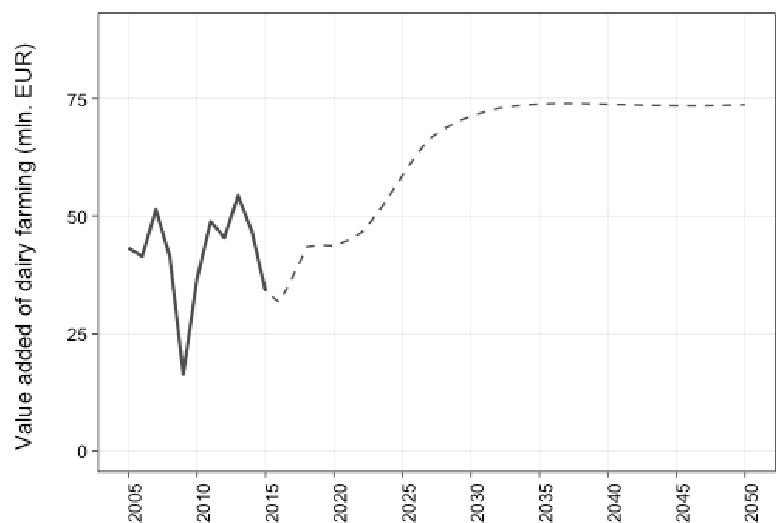

Fig. 3. Value added of dairy sector in 2005-2015 and projection of it in Latvia for period 2016-2050, mln. EUR $[13 ; 15 ; 16]$

The value added of the field crop sector is projected to reach EUR $281.8 \mathrm{mln}$. by 2050, which is almost 2.2 times more than in 2017 (EUR $128.8 \mathrm{mln}$.). However, the considerable fluctuations of value added have to be taken into consideration, because the increase is significantly smaller $-46 \%-$ if comparing the value added projected by 2050 and that reported in 2015 . The value added projected by 2030 at EUR $170.5 \mathrm{mln}$. exceeds that reported in 2017 by $32 \%$.

Based on the projections of the number of dairy cows and of milk yields, a considerable increase in the value added of the dairy sector is expected from 2017 onwards; the value added is projected to decrease after 2025 and stabilise at EUR $76 \mathrm{mln}$. after 2030 (Figure 3). The value added of dairy farms significantly decreased after the crisis; for this reason, the projected increase in value added is considerable as well. Compared with 2017, the value added is going to increase more than twofold by 2050 (from EUR $37.1 \mathrm{mln}$. to EUR $76.2 \mathrm{mln}$.).

Similar tendencies for the value added development were observed for other grazing livestock as well as granivores sectors. 


\section{Conclusions}

Value added is one of the key indicators in many policy documents. It is important to have this indicator in agricultural policy simulation tools in order to identify the potential development of this sector. The LASAM model for the agricultural sector in Latvia is extended and now can generate also value added indicators for field crops, vegetables, permanent crops, dairy, other grazing livestock, pigs and poultry. According to the baseline projections (if the CAP is frozen after 2020), the value added of agriculture in Latvia is expected to increase by $33 \%$ in 2030 and by $80 \%$ in 2050, compared with 2017. Growth is projected also in the key agricultural sectors until 2050: a 2.2-fold increase in field crops and a 2.1 -fold increase in dairy farming.

\section{Acknowledgements}

The research was promoted with the support of the project of the Ministry of Agriculture of the Republic of Latvia "Forecasting of Agricultural Development and the Designing of Scenarios for Policies until 2050", agreement No. 17-100-INV17-5-000023.

\section{References}

[1] European Commission, CAP at a glance. [online] [30.04.2017]. Available at: https://ec.europa.eu/agriculture/cap-overview_en

[2] European Commission. Special Eurobarometer 410. Europeans, Agriculture and the Common Agricultural Policy (CAP). March 2014, 126 p.

[3] OECD/FAO, OECD-FAO Agricultural Outlook 2016-2025, OECD Publishing, Paris, 2016, 138 p. [online] [22.12.2017]. Available at: http://dx.doi.org/10.1787/agr_outlook-2016-en

[4] Zemkopības ministrija. Latvijas lauksaimniecība 2017 (Ministry of Agriculture. Agriculture in Latvia 2017). Riga, 2017, 170 p. (in Latvian).

[5] Nipers A., Pilvere I., Bulderberga Z. Territorial Development Assessment In Latvia, Conference: 23rd Annual International Scientific Conference on Research for Rural Development Location: Latvia University of Agriculture, Jelgava, Latvia, May 17-19, 2017, pp. 126-134

[6] Salputra G., Chantreuil F., Hanrahan K., Donnellan T., Van Leeuwen M. Policy Harmonized Approach for the EU Agricultural Sector Modelling. Agricultural and Food Science, Vol. 20, 2011, pp. 119-130.

[7] Adenauer M. CAPRI versus AGLINK-COSIMO Two Partial Equilibrium Models - Two Baseline Approaches. 12th Congress of the European Association of Agricultural Economists - EAAE 2008, p. 4.

[8] Borshchev A., Filippov A. From System Dynamics and Discreet Event to Practical Agent Based Modelling: Reasons, Techniques, Tools. The 22nd International Conference of the System Dynamics Society, 25-29 July 2004, Oxford, England, p. 23.

[9] Alexandratos N., Bruinsma J. World agriculture towards 2030/2050: the 2012 revision. ESA Working paper No. 12-03. Rome, FAO, 2012, 160 p.

[10] Nipers A., Pilvere I., Zeverte-Rivza S. Projections for the Latvian Dairy and Beef Sector In: 16th International Scientific Conference "Engineering for Rural Development": Proceedings, Jelgava, Latvia, May 24 - 26, 2017, Vol. 16, pp. 546-554. [online] [14.01.2018]. Available at: DOI: 10.22616/ERDev2017.

[11]Zeverte-Rivza S., Nipers A., Pilvere I. Agricultural Production and Market Modelling Approaches. In: Economic Science for Rural Development: Proceedings of the International Scientific Conference, Nr. 45: Integrated and Sustainable Regional Development. Marketing and Sustainable Consumption, Jelgava, 2017, pp. 267-274. (WOS:000406530100032).

[12] Nipers A., Pilvere I., Zeverte-Rivza S., Krievina A. (2017) Use of Econometric Model for Developing an outlook for Livestock Sector in Latvia In: 16th International Scientific Conference "Engineering for Rural Development" : Proceedings, Jelgava, Latvia, May 24 - 26, Vol. 16, pp. 874-883. [tiešsaistrs resurss]. DOI: 10.22616/ERDev2017.16.N176

[13]Zinātniskā pētījuma Lauksaimniecības atțīstības prognozēěana un politikas scenāriju izstrāde līdz 2050. gadam projekta atskaite (Report on the Project Forecasting of Agricultural Development and the Designing of Scenarios for Policies until 2050). Jelgava: Latvia University of Agriculture, December 2017, 119 p. (in Latvian). 
[14] Centrālā statistikas pārvalde. Pievienotā vērtība (uzṇēmējdarbības rādītāji). (Central Statistical Bureau. Value Added) (in Latvian). [online] [18.12.2017]. Available at: http://www.csb.gov.lv/statistikas-temas/termini/pievienota-vertiba-uznemejdarbibas-raditaji37018.html

[15]Centrālā statistikas pārvalde. Lauksaimniecība, mežsaimniecība, zivsaimniecība datubāze. (Central Statistical Bureau. Agriculture, Forestry and Fishery database) (in Latvian). [online] [28.12.2017]. Available at: http://www.csb.gov.lv/statistikas-temas/termini/starppaterins34386.html

[16] SUDAT datu bāze (FADN database). Unpublished resource. (In Latvian). 